Int. J. Speleol. 10 (1978), pp. 303 - 322

\title{
Studies of the cave crayfish, Orconectes inermis inermis Cope (Decapoda, Cambaridae). Part IV: Mark- recapture procedures for estimating population size and movements of individuals
}

\author{
by
}

\author{
H. H. Hobbs III (1)
}

\section{INTRODUCTION}

The first account of the troglobitic crayfish Orconectes inermis inermis occurring in Indiana was by E. D. Cope, who in 1871 reported "Astacus pellucidus'to inhabit Wyandotte Cave. Since this early account, the crayfïsh has received considerable attention (Hobbs and Barr, 1972; and Hobbs, Hobbs, and Daniel, 1977). Yet, few data on its life history, behavior, and ecology are available (Jegla, 1965, 1966).

In this study an attempt has been made to determine the range of movements of individuals of. O. i. inermis in a stream flowing through Pless Cave in I awrence County, Indiana. All segments of the subterranean portion of the stream support a comparatively large population of this albinistic crayfish. Considerably less abundant are the three pigment-bearing crayfishes: Orconectes immunis (Hagen), Orconectes sloanii (Bundy), and Cambarus (Erehicambarus) laevis (Faxon). So few individuals of the pigmented crayfishes occurring in the cave were encountered that only passing references are made to them. See Hobbs III (1973 and 1975) for what few data are available concerning these animals.

Several investigators have studied the movement of crayfishes in epigean habitats and have developed various marking techniques for recognizing individuals (see Appendix). Only Jegla (1965) (as an aid in clarifying molting pe- 
riods and in obtaining a rough population estimate in Shiloh Cave, Indiana) and Cooper and Cooper $(1971,1976)$ (Shelta Cave, Alabama) have used tagging in studying subterranean crayfishes. In the present study, cave crayfishes were internally and externally marked and movement data based on sight and/or hand captures were recorded for individuals.

\section{STUDY AREA}

The study area, Pless Cave, lies within the Salem and St. louis limestone formations (Mississippian deposits) of the Mitchell Plain. The two entrances to the cave are located in the SE $1 / 4$, NE $1 / 4$, SE 1/4, Section 5, Township $4 \mathrm{~N}$, Range $1 \mathrm{~W}$ just southeast of the East Fork of White River, approximately 5 $\mathrm{km}$ southwest of Bedford, Lawrence County, Indiana, at an elevation of $149.1 \mathrm{~m}$. The Mid-Illinois Grotto of the National Speleological Society which has been mapping Pless Cave since 1967, has discovered nearly $5 \mathrm{~km}$ of cave passages.

The larger entrance to the Cave (Fig. 1) is in the face of a limestone bluff. 9.1 $\mathrm{m}$ high, which forms the head of a small winding valley. This valley, once part of the cave, now serves as a conduit for the stream that courses through the cave and exits via this entrance. In then flows northwest for approximately 0.8 $\mathrm{km}$ and empties into the East Fork of White River, with which it is at grade. A second "karst window" entrance to the cave is located some 30.5 meters upstream from the stream exit.

The cave passages range from 0.9 to $9.2 \mathrm{~m}$ in width and from 0.5 to $12.2 \mathrm{~m}$ in height. They follow along and are controlled by NS and EW trending joint systems, primarily within the Salem limestones and there is evidence that at one time the cave was much more extensive than at present (Palmer, 1968, 1969).

The major NE-SW trending stream flows the length of the Cave (Fig. 1) and is joined by a larger tributary from the south $160 \mathrm{~m}$ from the main entrance, and a minor one enters it from the north $410 \mathrm{~m}$ upstream. Numerous smaller "feeders" enter it along its entire course. During normal flow the stream ranges in depth from a few centimeters to $1 \mathrm{~m}$. Certain areas of the cave may flood to the ceiling, at times making access impossible. During periods of annual spring flooding the East Fork of White River backs up, flooding the valley northwest of the cave, inundating both entrances and an undetermined portion of the cavern passages. Along the course of the stream there are many pools from 0.3 to $0.9 \mathrm{~m}$ in depth, and a single pool in the north tributary passage is $2.4 \mathrm{~m}$ deep. Except following rains and spring thaws, the water is clear but becomes very turbid during flooding due primarily to clay and silt suspension. The composition of the substrate of the stream is quite variable: silt, sand, gravel, "breakdown," bedrock, and all combinations thereof. Large 


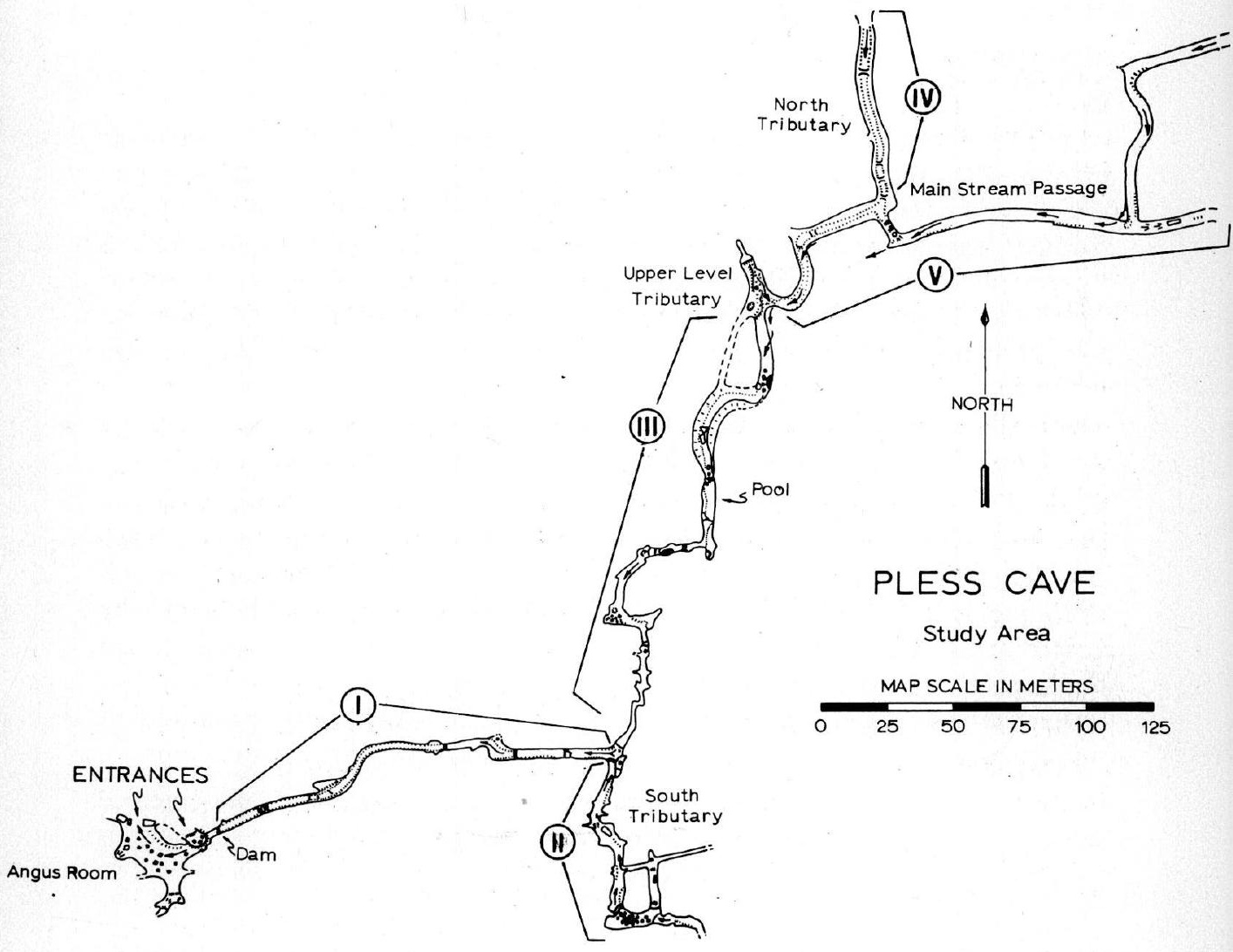

Figure 1. Map of Pless Cave study area showing five sections. 
mudbanks are prevalent throughout the cave and constitute a large portion of the stream substrate. To facilitate recording of data, the study area within the cave was divided into five sections, which are referred to throughout the text by number (Fig. 1).

\section{METHODS}

Prior to marking any crayfishes in the field, various tagging methods were tested in the laboratory. Speciemens were collected from both the cave environment and from surface streams west of Bloomington, Indiana, and transferred to cold rooms (semi-darkness at $13^{\circ} \mathrm{C}$ ). Since single crayfish were to be studied for a considerable time period, it was imperative that a "permanent" mark be utilized that would allow for individual identification. The initial approch was to clip appendages (Goellner, 1943). Observations on the behavior of numerous individuals so marked indicated that this method may influence the motility of the individuals. Moreover, the appendages are eventually regenerated, at times rather rapidly. Hence, it was decided to test a permanent mark produced by the injection of colored ink (Slack, 1955).

Using a $2 \mathrm{ml}$ syringe and a No. 23 needle, Bates Numbering Machine Ink (No. 4929A) was injected into the abdominal segments of surface and cave crayfishes. Marking was dorsal in $O$. $i$. inermis because of the absence of masking pigment in the exoskeleton and to eliminate any possible damage to the ventromedian nerve cord (the marks also could be readily seen on crayfishes in the stream). The needle was inserted (into the muscle) lateral to midline between the abdominal segments and posterior to the segment to be marked. A minute amount of ink was injected, leaving a small distinct colored spot.

Because the surface dwelling crayfishes are heavily pigmented, ink injected dorsally is not readily visible. However, the ventral side of their abdomen is encased in a thin, translucent cuticle through which ventral marks proved to be quite visible.

Some crayfishes were tagged using red, blue, and black Numbering Machine Ink combinations; some were tagged only with Wesson Oil (used to dilute ink); and others were stuck with the needle or left untagged. In less than a month nearly $30 \%$ of the epigean specimens from all groups were dead, but all groups of the troglobitic subspecies remained in apparent good health and without any mortality. These data suggested that some unknown extrinsic environmental factor, not the material injected, was responsible for the high mortality of the epigean species. To substantiate this, 10 specimens of $O$. propinquus (Girard) and five of $C$. (E.) laevis were collected from surface streams and placed in environmental chambers in constant darkness. Within two weeks, four specimens of $O$. propinquus and one $C$. laevis were dead. In both 
species, camnibalism may have been involved, although all the $O$. propinquus were dead within five weeks after capture. The remaining $C$. laevis lived several months and were then released. All tagged troglobitic Orconectes survived in the laboratory, confirming the belief that these crayfishes are not appreciably injured by the tagging method. Additional $O$. $i$. inermis were injected with unsterilized needles without mortality or infection. Thus, to speed work in the ficld, sterilization was omitted.

Several of the original crayfishes lived in the laboratory through two successful molts, and in all the individuals, the internal tag remained unchanged. In the fïcld, however, after approximately a year and a half, the ink began to fade. Fading was especially obvious in certain individuals marked with blue or black colors. Since red was retained clearly the longest, it is the most reliable color of Bates Ink for an internal tag. Even with fading of the other ink colors, tagged individuals were relatively easy to recognize, as the area around the injection sites assumed a dark brown color, foming a "stain", or "scar," in the exoskeleton. The additional records of length, sex, morphological variations, and injuries recorded at the time of initial capture, as well as at each recapture, made the identification of marked crayfishes certain in all except a very few instances. Subsequent visits to the cave demostrated that the internal tags last longer than was originally anticipated. A male crayfish was injected with blue ink on 5 July 1971. On 22 May 1977 (5 years, 10 months from initial tagging) the individual was again recaptured and the tag was still quite clearly recognizable.

In addition to the internal tag, the crayfish were marked externally in the same pattern with colored fingernail polish. Also, the number of the study section (Fig. 1) in which the individual was captured was painted on the dorsal side of the cephalothorax. These external marks not only enabled identifications to be made without disturbing the individuals, but also aided in determing whether or not the crayfish had molted since last observed.

More individuals could be tagged with one color of ink if all the abdominal segments (in various combinations) were marked, but since "bleeding" of the ink sometimes occurred at injection, with small amounts of ink "leaking" into the adjacent areas, only alternate segments were marked. The system of identification employed is depicted in Fig. 2. Use of multiple color combinations allowed a sufficient number of combinations for distinctive tagging. The initial procedure of marking and recording data in the field required approximately ten minutes per individual.

The following information was recorded for each crayfish when first marked and at each recapture or sighting: carapace length in $\mathrm{mm}$, sex. (form) in males; females if ovigerous or not, and with or without cement glands, eggs, or 


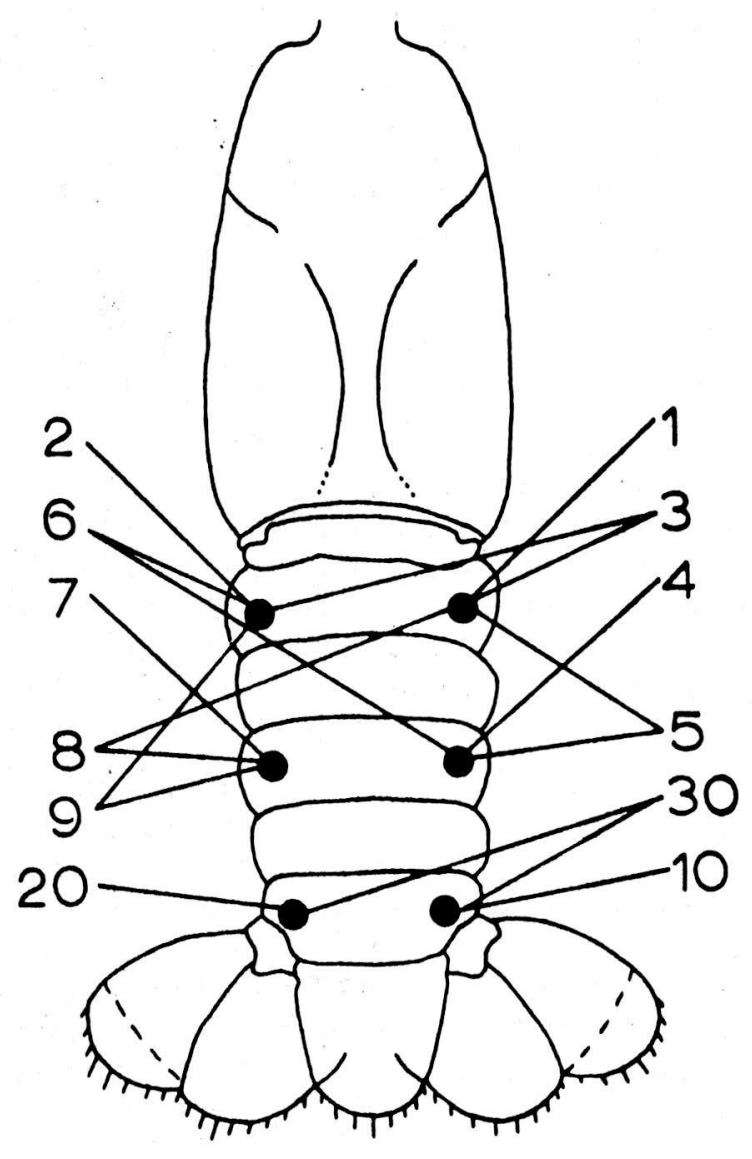

Figure 2. Dorsal view of generalized crayfish, showing system for numerically marking individual cratiolies in Pless (ave.

young), injuries and regenerated appendages and molt state. The location of capture of the crayfishes was noted along with the type of substrate, the amount and kind of potential food (leaf, stick, etc.) if present, and the animals were released into the stream at the site of capture. Their actions upon release were also observed. A wire with an acetate flag was inserted in the mud banks when the crayfish was first captured so that the distances (upstream and downstream) subsequently traveled by each individual could be determined. 
The code number of the crayfish marked was scratched into the acetate.

\section{RESULTS}

\section{Estimates of population size:}

The first crayfish was marked on 7 November 1970, and the last individual was injected on 12 February 1972. During this 16-month period a total of 226 crayfishes was tagged; $211 \mathrm{O}$. i. inermis, $2 \mathrm{O}$. immunis, and $13 \mathrm{C}$. laevis. During the period of study, October 1970 to September 1972, 96 tagged individuals of $O$. $i$. inermis were recaptured at least once for $46 \%$ recapture rate. One $O$. immunis and 5 individuals of $C$. laevis were observed subsequent to being marked, a recapture rate of 50 and $38 \%$ respectively.

Estimates of the population size of $O$. $i$. inermis in the cave were made using the Schumacher-Eschemeyer Index (Schumacher and Eschmeyer, 1943; Hobbs, 1977). Since the study area was divided into five sections, and all were not sampled equally (problems with flooding), an estimate of the size of the population is presented for three of the sections and a summation of these is given as an estimate of the total population size. Due in part to infrequent sampling only one and no recaptures were recorded from Sections II and IV, respectively, thus they have been omitted from the sectional estimates.

In most investigations of home ranges, only individuals captured three or more times over a certain period (3-4 weeks) are considered in analyses; however, in this study several factors led to the use of all movement data from all tagged individuals: the population was relatively small (compared to epigean populations), traps with attractant baits were not used (all crayfishes were caught by hand or with the aid of a dip net), a large portion of the study area was not physically disturbed by the researcher, and the crayfishes tended to remain in open, unprotected areas, regardless of physical perturbations (excluding spates). The time elapsed between captures varied from one to 558 days, with a mean time interval of 66 days.

The population estimate of $O$. $i$. inermis in Section I was 380 individuals within $160 \mathrm{~m}(23.8$ crayfishes per $10 \mathrm{~m})$; the $95 \%$ confidence limits for the size of the population in this section are 301 and 458 .

The population estimate for the same species in Section III was 694 within a linear distance of $235 \mathrm{~m}$, or 29.5 crayfish per $10 \mathrm{~m}(95 \%$ confidence limits of 516 and 872 individuals).

Section $V$ was estimated to support a population of 512 O. i. inermis over 145 $\mathrm{m}(35.3$ crayfish per $10 \mathrm{~m})$; the $95 \%$ confidence limits are 317 and 708 craylish.

C'ombining the three sections, the size of the population of $O$. i. inermis was 


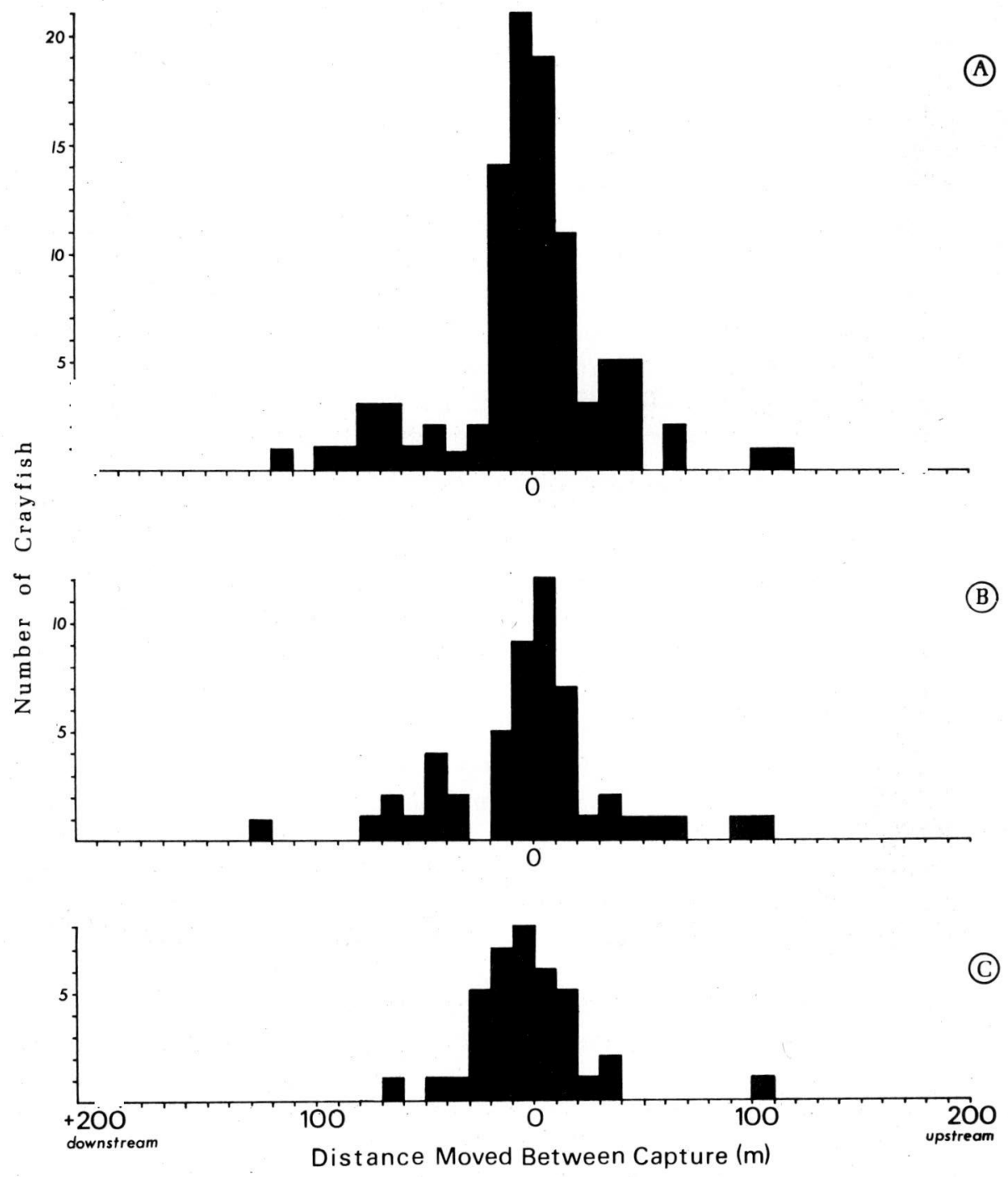

Figure 3. Histogram of the distances and directions mosed between captures by corenectes imermis inermis in Pless Cave.
A. Distances moved by females.
B. Distances moved by Form I males.
C. Distances moved by Form II males.

estimated to be 1586 within 54() $\mathrm{m}$ of the stream: one crayfish per $(0.34 \mathrm{~m}$, or 29 individuals per $10 \mathrm{~m}(95 \%$ confidence limits of $15(07$ and 1665$)$. 

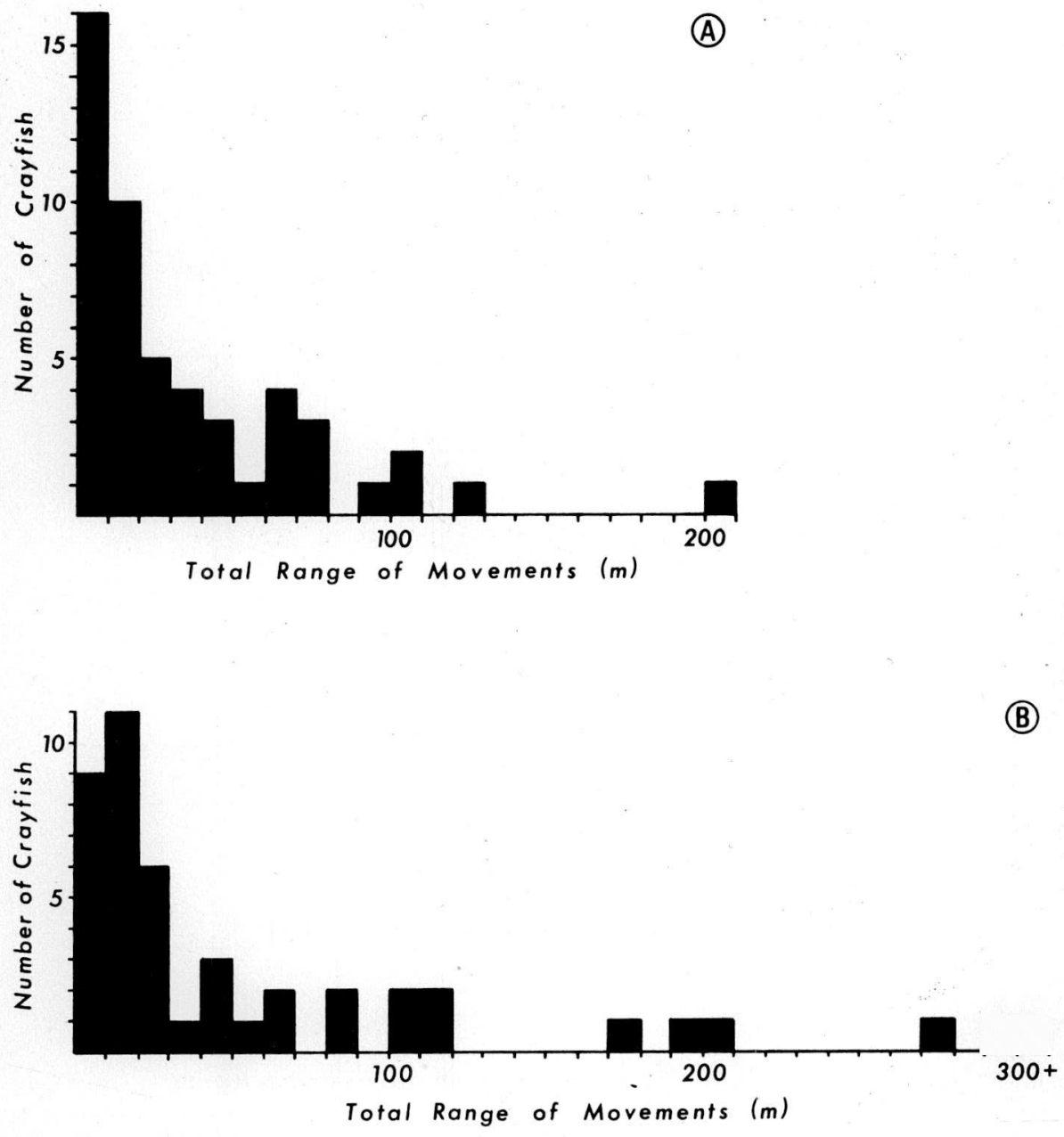

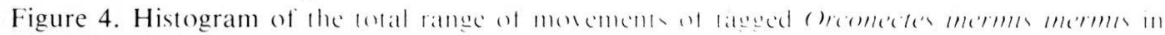
Pless Cave.

A. Range of movements of malcs

B. Range of movements of limales

\section{Range of Activity}

Data on the movements of the 96 tagged (). i. incrmis that were recaptured were analyzed by plotting the number of indis iduals agains the distance trat-

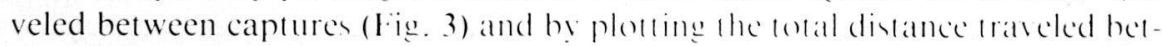
ween maximum upstream and downstream positions (total range of mosements) for males and females (Fig. 4). Monement wat considered to be poritive (upstream) or negative (downdream) from the plate where the andmal wats first captured. 
Table 1. Movement of Orconectes inermis inermis from the point of latest capture as a function of sex.

\begin{tabular}{|c|c|c|c|c|}
\hline & \multirow{2}{*}{\multicolumn{2}{|c|}{$\begin{array}{lc}\text { Statistic } & \text { Standard Error } \\
& \text { Form I Males }(\mathrm{N}=51)\end{array}$}} & \multicolumn{2}{|c|}{$\begin{array}{c}\text { Confidence I.imits } \\
(95 \%)\end{array}$} \\
\hline & & & & \\
\hline Mean & 2.24 & 5.42 & -13.13 & 8.66 \\
\hline Median & 0.00 & 5.80 & -13.66 & 13.66 \\
\hline $\mathrm{G}_{1}$ & -.05 & .33 & -.71 & .60 \\
\hline $\mathrm{G}_{2}$ & 2.30 & .66 & 1.01 & 3.58 \\
\hline \multicolumn{5}{|c|}{ Form II Males $(\mathbf{N}=38)$} \\
\hline Mean & -7.50 & 6.79 & -21.27 & 6.27 \\
\hline Median & -5.00 & 8.52 & -22.25 & 12.25 \\
\hline $\mathrm{G}_{1}$ & -2.14 & .38 & -2.89 & -1.85 \\
\hline $\mathrm{G}_{2}$ & 12.38 & .75 & 10.91 & 13.85 \\
\hline \multicolumn{5}{|c|}{ Females $(N=102)$} \\
\hline Mean & -13.04 & 7.96 & -28.84 & 2.77 \\
\hline Median & -2.00 & 3.87 & -21.81 & 17.81 \\
\hline $\mathrm{G}_{1}$ & -3.82 & .24 & -4.29 & -3.36 \\
\hline $\mathrm{G}_{2}$ & 22.41 & .47 & 21.48 & 23.34 \\
\hline
\end{tabular}

Table 2. Total range movements as a function of sex for Orconectes inermis inermis.

\begin{tabular}{|c|c|c|c|c|}
\hline & \multirow[t]{2}{*}{ Statistic } & Error & \multicolumn{2}{|c|}{$\begin{array}{c}\text { Confidence Limits } \\
(95 \%)\end{array}$} \\
\hline \multicolumn{4}{|c|}{ Males $(\mathbf{N}=\mathbf{5 1})$. } & \\
\hline Mean & 35.47 & 5.53 & 24.35 & 46.59 \\
\hline Median & 20.00 & 6.93 & 6.06 & 33.94 \\
\hline $\mathrm{G}_{1}$ & 2.07 & .33 & 1.42 & 2.73 \\
\hline $\mathrm{G}_{2}$ & 5.63 & .66 & 4.35 & 6.92 \\
\hline \multicolumn{5}{|c|}{ Females $(N=45)$} \\
\hline Mean & 67.44 & 15.58 & 36.03 & 98.86 \\
\hline Median & 23.00 & 19.53 & -16.37 & 62.37 \\
\hline $\mathrm{Gl}$ & 3.12 & .35 & 2.43 & 3.81 \\
\hline $\mathrm{G}_{2}$ & 12.00 & .69 & 10.64 & 13.36 \\
\hline
\end{tabular}


Skewness to the right is positive, or in the upstream direction, while skewness to the left indicates the downstream direction. The g/ statistic which tests for skewness of curves, was employed, and a g2 test was used to check for kurtosis. A t-test was used and $95 \%$ confidence limits of the mean, median, and $\mathrm{g}_{1}$ and $g_{2}$ statistics were calculated (Tables 1 and 2). These calculations were made utilizing computer program A3.1 of Sokal and Rolf (1969).

When distances traveled between captures are plotted against the number of individuals negotiating them (Fig. 3) the mean distance moved is $-2.24 \mathrm{~m}$ (downstream) for Form I (breeding) males; the curve is not skewed but is leptokurtic (Table 1). The mean distance moved by Form II (non-breeding) males is $-7.50 \mathrm{~m}$, and the curve is skewed to the left and leptokurtic (Fig. 3C). Because the curve is negatively skewed and because the extreme values of distances moved exert a heavy influence upon the mean value, the median value of $-5.00 \mathrm{~m}$ is believed to be a more realistic representation of "average" movements of Form II males. For example, one crayfish was displaced $198 \mathrm{~m}$ downstream coincident with heavy precipitation and flooding of the stream. The mean distance moved by females is $-13.04 \mathrm{~m}$, and the curve is significantly skewed to the left and leptokurtic. Again, the use of the median value $(-2.00 \mathrm{~m})$ is believed to be a more accurate estimate of their average movements within the stream.

When the total range of movements (maximum upstream to maximum downstream) is plotted as a function of sex, males (both of I and $\delta$ II) are shown to have a mean center of activity (home range) of $35.5 \mathrm{~m}$ (Fig. 4). The curve is significantly skewed to the right and leptokurtic. The mean home range of females is $67.4 \mathrm{~m}$ and the curve also is skewed to the right and leptokurtic (Table 2 ). In both sexes, the range of movements varies considerably, with the maximum in males being as much as $204 \mathrm{~m}$ and of females, $571 \mathrm{~m}$. Since the majority of movements, however, are less than $100 \mathrm{~m}$, the plots are skewed significantly. Thus, the median values $(20.0 \mathrm{~m}$ for males and $23.0 \mathrm{~m}$ for females $)$ are believed to represent a more accurate estimate of the range of activity (Hobbs, 1977).

Many of the downstream movements of crayfish can be correlated directly with rainfall and melting snow and ice. The smallest female tagged $(16.9 \mathrm{~mm}$ carapace length) had moved $556 \mathrm{~m}$ downstream between 18 August and 7 October 1971. During this 49-day period, $14.02 \mathrm{~cm}$ of rain had fallen, of which $3.25 \mathrm{~cm}$ fell during one 24 -hour period and $3.33 \mathrm{~cm}$ during another. With such precipitation, the cave floods rapidly, and any crayfish that do not seek refuge are likely to be swept downstream. This does not imply that all downstream movements of crayfish are the result of flooding, nor does it imply that most crayfish are forced downstream with each flood. Quite obviously many crayfish were not effectively displaced by increased water flow. 

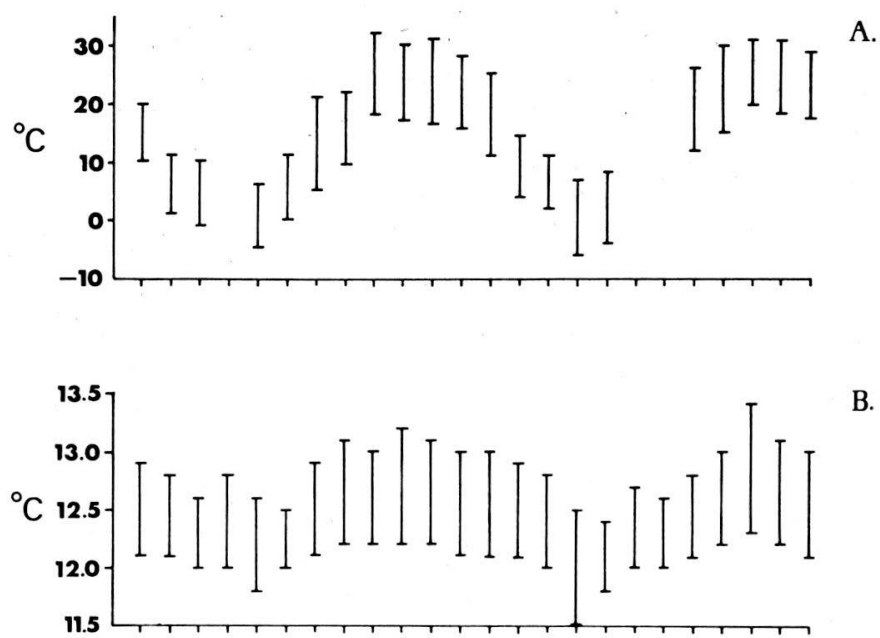

B.

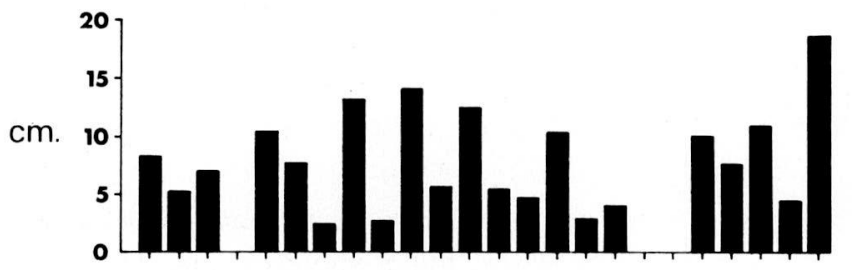

C.

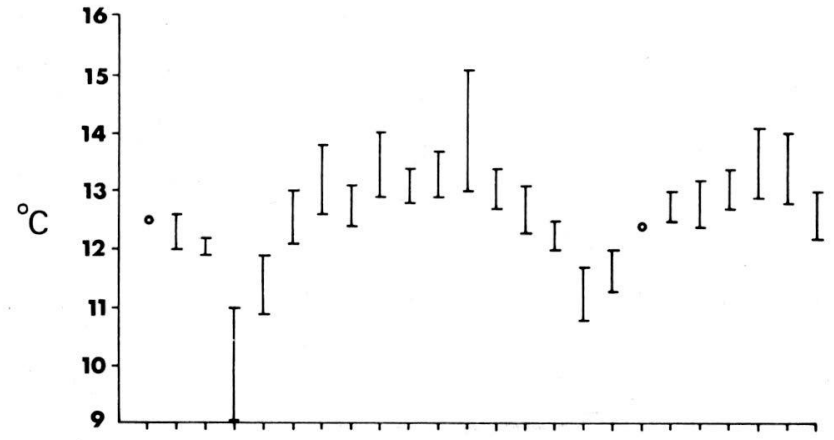

D.

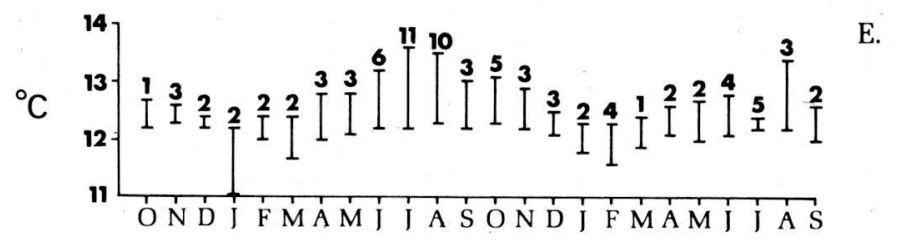




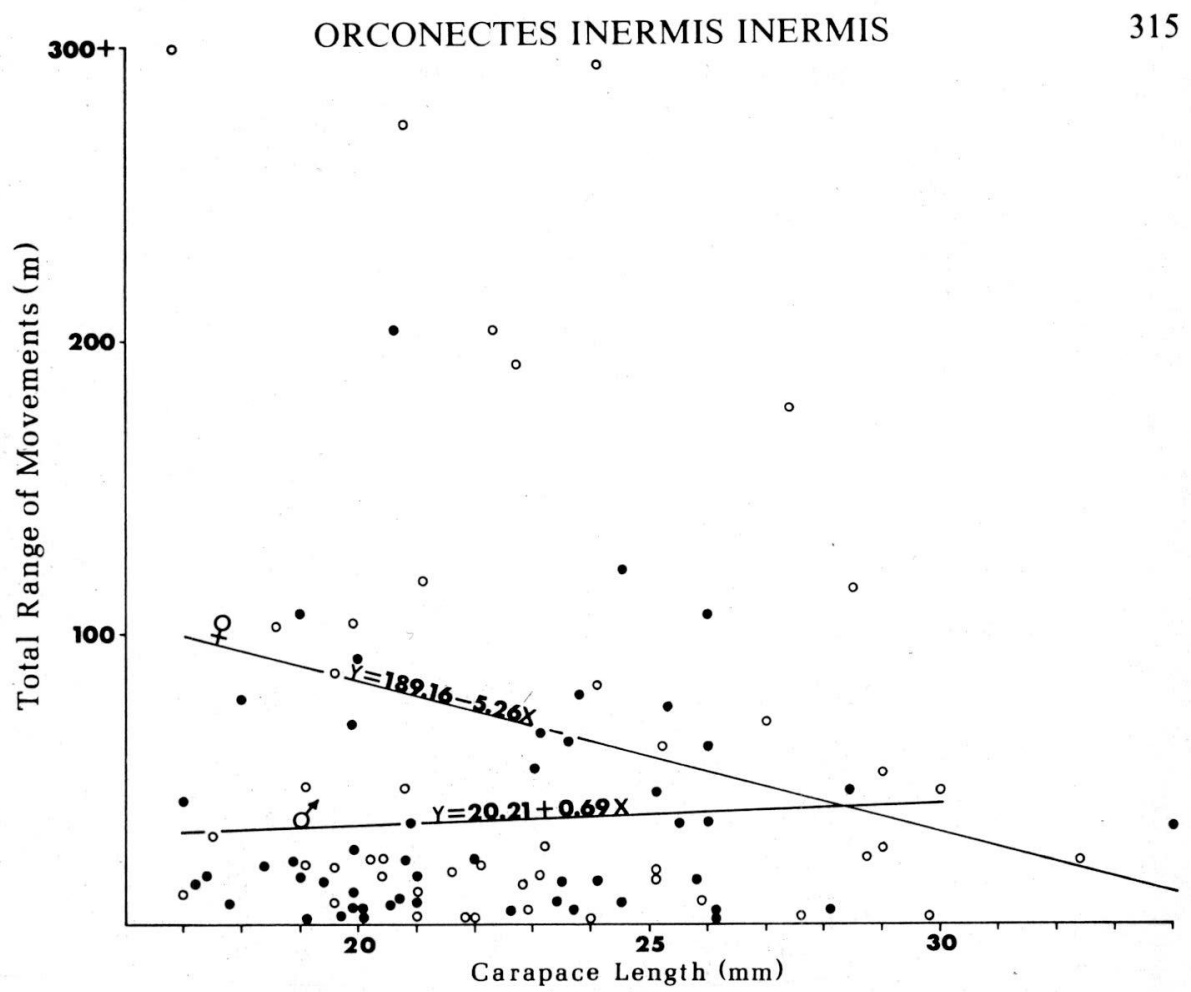

Figure 6. Plot of total range of movements vs carapace length of tagged Orconectes inermis inermis in Pless (ave (open circles - females; filled circles - males).

Precipitation data for the Bedford, Indiana, area and air and water temperatures are presented (Fig. 5) for the cave interior and for the surface $32 \mathrm{~m}$ from the larger entrance. As can be noted, air and water temperatures remained relatively constant deep within the cave, varyng only a maximum of 2.6 and $2.5^{\circ} \mathrm{C}$, respectively. As expected, the epigean values fluctuated considerably. Distances traveled between recaptures are not directly related to the time elapsed. For example, one female was found only $2 \mathrm{~m}$ upstream after 558 days, whereas another female had moved $74 \mathrm{~m}$ downstream in only five days.

Total range of movements plotted against carapace length yielded significant $(P<0.05)$ linear regressions for both sexes (Fig. 6), with regression coefficients of 0.69 for males and -5.26 for females. Thus, small females have a considerably larger total range of movements than large females, whereas large

Figure 5. A. Mean monthly minimum and maximum epigean temperature values for Bedford, Indiana area for October 1970 through September 1972 (Pless Cave).

B. Minimum-maximum air temperature values for Pless Cave.

('. Precipitation values for Bedford, Indiana.

1). Minimum-maximum water temperature values for surface stream effluent (32 $\mathrm{m}$ downstream from large entrance) from Pless (ave.

I: Minimum-maximum water temperature values for Pless Cave. Numbers above each monthly plot represent number of trips to cave. 


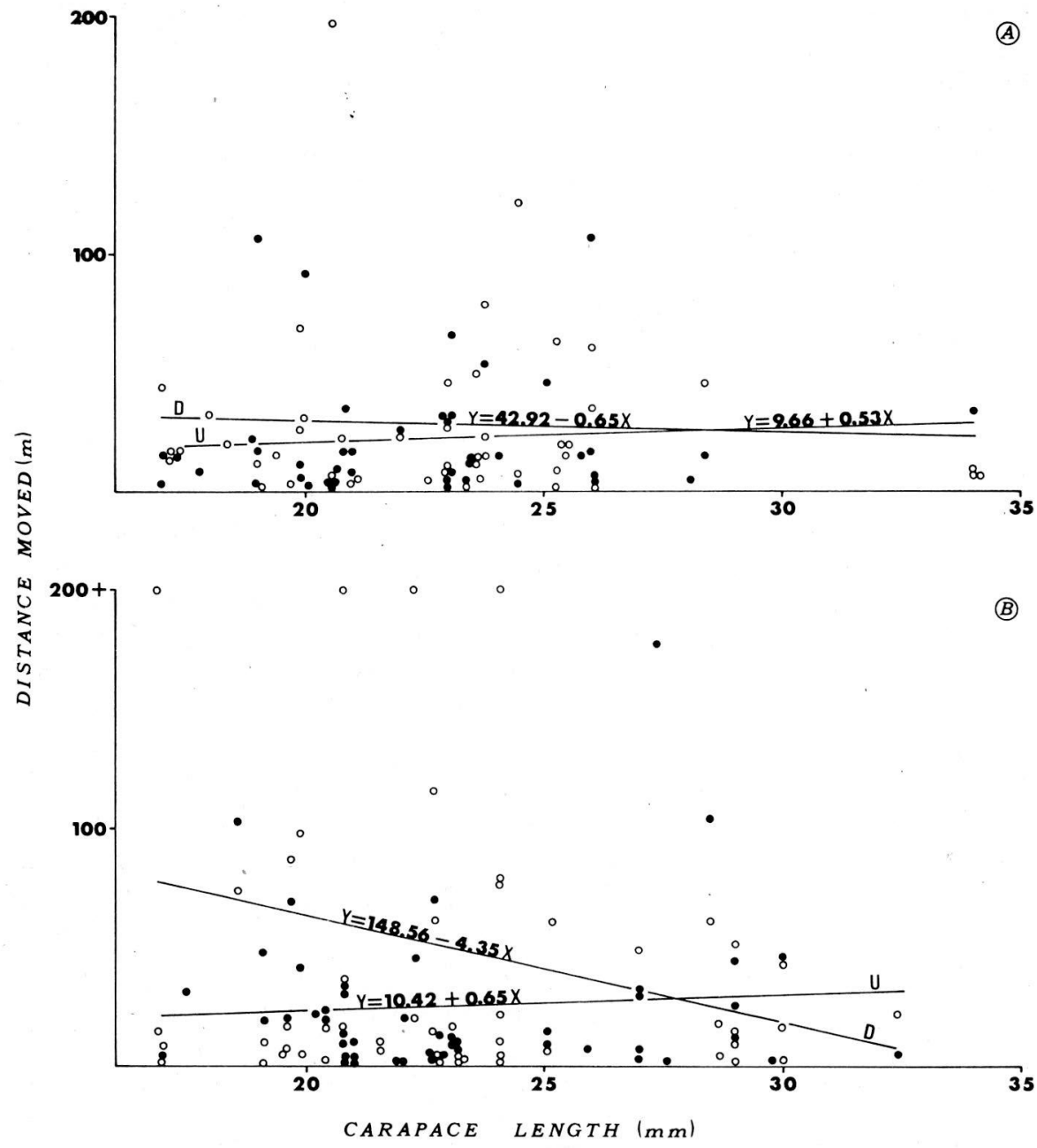

Figure 7. Plot of upstream (U) and downstram (D) movements vs carapace lengths of tagged Orconectes inermis inermis in Pless Cave (open circles - downstream movements; filled circles - upstream movements). A. Males B. Females 
males have a somewhat greater range of movements than small ones. Separate analyses of upstream movements and downstream movements as a function of size of individual (carapace length) show that (Fig. 7) smaller individuals of both sexes tend to be displaced greater distances downstream whereas larger individuals exhibit a greater upstream movement. Although all the regression coefficients are significant $(P<0.05)$, the upstream movements of males and females with respect to size are quite similar, whereas the regression of downstream displacement of females has a much steeper negative slope than that of males, indicating that small females are more readly displaced downstream and for greater distances than small males.

Very few juvenile crayfishes were observed during this study and thus no attempt is made to examine the positions of these young age groups relative to larger males and females.

\section{DISCUSSION}

Based on the data presented above, 1586 crayfish $( \pm 79,95 \%$ confidence limits) inhabit the study area. If the estimate of one crayfish for every $0.34 \mathrm{~m}$ of stream passage is reasonable for the entire system, there would be approximately 2941 crayfish per $\mathrm{km}$. The estimated $3 \mathrm{~km}$ of stream passage would thus harbor a total population of 8823 individuals. The stream, however, is not homogeneous throughout its course. It varies not only in depth, flow, and gradient, but also the substrate is quite diverse. Furthermore, the density of crayfish is apparently higher in areas where organic debris has accumulated. Thus, such an estimate of the total cave population is undoubtedly excessive.

Leptokurtosis and/or skewness in many of the plotted curves suggest that movement of $O$. i. inermis is not random. Leptokurtosis indicates grouping around the mean, and skewness reflects the direction of net movement of individuals. Hence, it is apparent that individual $O$. $i$. inermis tend to remain in a restricted area, with moderate movement both up and downstream. This area for males is about $20 \mathrm{~m}$ and for females about $23 \mathrm{~m}$. These centers of activity, or home ranges, of individuals overlap the ranges of others, thus generating competition for food, space, mating partners, etc. Where these home ranges are invaded by $C$. (E.) laevis, additional stress is placed on individuals for food and space. These centers of activity for both sexes apparently are not constant throughout the lives of the individuals, as indicated by the net downstream movements between captures of individuals $(-2.24 \mathrm{~m}$ for Form I males, -5.00 $\mathrm{m}$ for Form II males, and $-2.00 \mathrm{~m}$ for females). Thus the population, although stable with respect to total numbers observed in the cave during the study period, appears to be slowly moving downstream (out of the cave? - no $O$. $i$. inermis has ever been observed in the epigean portion of the stream), and 
may be restocked from the upstream portions of the cave. Such net downstream movement is due in part to flooding and perhaps also in part to population pressures. Any time interaction occurs (inter - or intraspecific), the "fitness" of the environment is reduced, as the cave crayfish is strictly solitary except during the mating period, or whenever food accumulates in pools and when females are carrying young. Also, they are constantly using energy to maintain their position in the stream. If the population density increases to a level at which interactions become excessive (increasing competition for food, space, and mates, sometimes resulting in loss of appendages) then it seems highly probable that migration would occur. The physical pressure of the current to force individuals downstream probably would become quite an important factor under such population pressure or densities. Although only hypothetical, it is likely that if voluntary migration-displacement (not the result of spates) should occur, it would peak with the release of young or when there is organic input into the system, in as much as individuals congregate in areas where organic debris (potential food) has accumulated.

The size of the home range of $O$. $i$. inermis in Pless Cave appears to be related to the size of the animal, its sex and stage of reproduction. The values of distances traveled between captures demonstrate that Form I males are less active and travel shorter distances than do Form II males; however, both demonstrate a net downstream movement. Large adult females exhibited less movement than small adults and/or juveniles (Fig. 6, 7); this is primarily the result of small crayfishes being washed downstream during spates. Females also exhibit a net downstream movement. Comparing movements of all males and females, the range of activity of males is slightly less than those of females (median $=20$ and $23 \mathrm{~m}$ respectively). Interpretation of these data is somewhat difficult, in light of what is known of the activity of other crayfishes. A short term study of Orconectes inermis testii (Hay) in Mayfield's Cave, Monroe County, Indiana, during September 1969 to March 1970 showed that the size of the home range of this species does not appear to be related to the size of the animals, per se, but it does seem to correlate to sex and stage of reproduction (Hobbs, 1973). Greater activity of males is closely linked to the reproductive cycle of $O$. $i$. testii in Mayfield's Cave. Why this is not demonstrated in Pless Cave by $O$. $i$. inermis is not fully understood, but possibly the greater amount of flooding and the presence of detrital food mats may significantly affect the displacement of individuals of this species.

Contrary to individuals of $O$. $i$. inermis, the tendency to move upstream seems to dominate over the downstream movements of $O$. $i$. testii [(mainly Form I males in Mayfield's (ave (Hobbs, 1973)]. Fifteen individuals (65\%) were observed to move upstream and $8(35 \%)$ were found to move downstream from their tagged location (based on the final position relative to marking). These 
data agree with the observations of Minckley (1964), Momot (1966), and Elliott (1971) that certain aquatic invertebrates exhibit extensive upstream movement, although not necessarily as a compensatory movement for downstream displacement following floods. This was not the case in Pless Cave where movement data support the proposal of Momot (1966) and Waters (1961) that flooding results primarily in downstream displacement. This may be a peculiar response of the crayfish inhabiting this particular cave, since the subterranean aquifers respond rapidly to precipitation and receive large volumes of water from considerable surface drainage.

Greatest densities of crayfishes occur "where the stream gradient is minimal, where there is a sufficient supply of food (organic detritus), and where the substrate is mud and silt rather than stones or bedrock. In areas of low stream gradient, where there are pools and the flow is retardeds, the substrate consists of mud with a silt cover and quantities of allochthonous detritus. Because these conditions invariably occur together, it is very difficult to isolate one of them as being most important in influencing the aggregation of crayfishes there. Thus, there exists an apparent correlation of highest population density with a silt-detritus substrate... Food, however, is one of the major limiting factors in the spelean environment. Thus, cavernicolous crayfishes abandon, for the most part, areas of the stream where their preferred substrate [rock-gravel] exists to frequent areas in which the limited food tends to be concentrated in the form of detritus" (Hobbs, 1976: 408). In areas where food accumulated, particularly in pools in Sections I and III, individuals were quite numerous. No crayfish were observed fighting during the study, however, interand intraspecific contacts no doubt occasionally occur where individuals are at a distance of less than $0.5 \mathrm{~m}$, the "awareness distance" (Hobbs, 1976: 409); such encounters have been observed in other cave populations in southern Indiana. Territorial spacing, per se, has not been shown to occur within this species; however, laboratory behavioral studies and examination of pheromone production and sensitivity of this cavernicole are presently being conducted.

As pointed out, in this heterotrophic environment energy is an extremely limiting factor. To exist in such a habitat, numerous adaptations have evolved to aid the species in coping with the stresses of the enironment. Data indicate (number of crayfish observed in each section per trip to cave) that the population remains relatively stable with respect to density. This is a situation where the aquatic community is relatively low in diversity, yet it remains stable due to the interactions of density-dependent and independent factors (i. e., population pressures, competition, and flooding) restocking from upstream sections of the cave, reduced metabolic rate, and a somewhat static halance between the species' biotic potential and mortality rates. The aquatic community of Pless Cave consists of the microbes associated with the substrate detrital 
mats, the amphipod Crangonyx packardi Smith, the isopod Caecidotea stygia Packard, the copepod Atheyella pilosa (Chappuis) which was found only as an ectocommensal on crayfishes, an undetermined peritrich ciliate protozoan on the exoskeleton of many crayfishes, the common pickerel frog Rana palustris LeConte (observed only once near the second entrance), and the four species of crayfishes. Of these, only the troglobitic crayfish is abundant throughout the cave and it is apparent that the number of trophic levels is small (never greater than and usually less than four: vegetative detritus, bacteria, isopods and/or amphipods, and crayfish). Many factors can affect the number of species present, such as food supply, environmental rigor (i.e., flooding), environmental variability and predictability, competition, and predation. The cave environment is certainly stable compared with epigean environments and the major perturbation (flooding) is generally predictable. Cave crayfish rarely, if ever, serve as prey to other organisms in Pless Cave, thus, it would appear that food supply is the prime limiting factor affecting the success of populations in the cave; yet, the stability of the population of $O$. $i$. inermis remains nearly static. The diversity-stability hypothesis states that complex trophic systems will be more stable than simple ones, or generally it predicts that diverse communities will remain more stable than less diverse ones (Goodman, 1975). These data add support to the observations presented by Goodman (1975) that "Clearly, the belief that more diverse communities are more stable is without support."

Considerable additional data on fecundity, immigration, emigration, and mortality rates are required for a better understanding of the population dynamics of the obligate cavernicole, $O$. i. inermis.

\section{ACKNOWLEDGMENTS}

I am grateful to Dr. David (i. Frey for his continuous support and encouragement during this study and to Drs. Horton H. Hohbs, Jr., and Donald P. Kelso for their helpful remarks concerning this manuscript. Special thanh are alse due to those persons who spent many hours underground with me: Messrs. Kenneth M. Burdsall, ( harkes I. Davis, Iric Hattleburg. Mark Jancin, James H. Keith, Paul W. Koeneman, Joseph Lucas, Michael (. Noore, Richard I. Powell, and Norbert Welch. I am deeply indepted to my wife, Susan, for her help and encouragememt

Ihis rescarch was atided by the financial assistance of a Doctoral Student Grant-in-aid of Research Fellowship (Indiana (Iniversity), a (ave Research Foundation (iraduate Fellowship, and a Sigma Xi Grant-in-aid of Rewatrh.

\section{SUMMARY}

Several methods for permanently marking cavernicolous crayfishes were investigated prior to initiation of field work in Pless (avc, I awrence county. Indiana. Internally injected ink complemented with external "painting" proved to be a most satisfactory tagging procedure. During the two-year study period 211 individuals of the troglobitic cravfish Orconectes inermis inermis Cope were marked; 96 tagged individuals were recaptured at least once, a $460^{\circ}$ recapture rate. The population size was estimated to be $1586 \pm 79(95 \%$ C.L.) over the $540 \mathrm{~m}$ subterrancin vream vudy area and remained relatively stable during the period of 1970 to 1972.

The home range of male crayfishes is as high as $20 \mathrm{~m}$ and extends up to $23 \mathrm{~m}$ for females, although maximum divance tratseled by individuals of hoth sexes greatly exceed these values. Small individuals of both sexes are diplated dewnstrcam wherea larger crayfish show distinct upstream movement. If all movement data are pooled, both sever evhibit a net downsteam movement. The downstream movement of erayfish is heavily influenced by llowding. 


\section{RÉSUMÉ}

Avant d'entreprendre le travail sur le terrain, dans la grotte Pless (Lawrence County, Indiana), nous avons testé plusieurs mëthodes afin de marquer d'une façon permanente des écrevisses cavernicoles. La méthode qui consiste en un marquage à la fois interne par injection d'encre et externe par des traces de peinture s'est avérée être très satisfaisante. Durant l'étude qui s'est étalée sur deux ans, 211 individus de l'espèce troglobie Orconectes inermis inermis Cope ont été marqués. 96 d'entre eux ont été recapturés au moins une fois, ce qui donne un taux de recapture de $46 \%$. L'effectif de la population a été estimé à $1586 \pm 79$ (intervalle de confiance $95 \%$ ) sur 540 $\mathrm{m}$ de rivière souterraine qui correspondent à la zone étudiée. Cet effectif est resté stable entre 1970 et 1972. Le territoire des écrevisses mâles s'étend sur $20 \mathrm{~m}$, celui des femelles va jusqu'à $23 \mathrm{~m}$, bien que les distances parcourues par les individus des deux sexes soient bien supérieures à ces valeurs. Les individus de petite taille des deux sexes sont entraînes en aval sur de plus grandes distances, tandis que les grosses écrevisses montrent un déplacement net vers l'amont. Si tous les résultats relatifs à ces déplacements sont additonnés, les deux scxes mon trent une nette tendance à se déplacer vers l'aval; ce mouvement est fortement influencé par les inondations.

\section{APPENDIX}

Various tagging techniques have been developed that allow for recognition of individual crayfishes and lobsters. Langlois (1937) was first to employ a tagging device, utilizing a metal square fastened to a wire which was inserted between the abdominal segments. Penn (1943) used small celluloid discs but found this method to be unsatisfactory in studyng Procambarus clarkii (Girard). Goellner (1943), Momot (1966), Merkle (1967), and Hazlett et al. (1974) clipped appendages, and Appelov (1909), Arwidsson (1914), and Svardson (1948) employed a similar method of extirpation. George (1957, 1958), in studying the West Australian marine spiny lobster Panularus longipes (Milne Edwards), punched distinctively shaped holes in the telson and uropods. Rounsefell and Everhart (1953) marked lobsters by attaching tags to a band encircling the carapace or extending from the rostrum to the telson. Slack (1955), Black (1963) Moberly and Pfrimmer (1967), Cooper and Cooper $(1971,1976)$ and Hobbs (1977) used Bates Numbering machine Ink to inject a definite mark between the cuticle and muscle. Prins (1968) used black Roberts ink in studying Orconectes rusticus (Girard) and Cambarus (E.) tenebrosus Hay in Kentucky. Merkle (1969) inserted a piece of $\mathrm{Co}^{60}$ alloy wire into the ventral abdominal muscle and used Goellner's method (1943) for marking individuals. Camougis and Hichar (1959), Jegla (1965, 1966), and Cooper and Cooper (1971) painted fingernail polish on the exoskeleton as a marking method. Abrahamsson (1965) marked Astacus astacus Linné by local cauterization on the carapace. Scarrett (1970) experimented with mechanical tags consisting of a filament and label. All of the above methods, except those of Slack (1955) and "his followers" and Abrahamsson (1965) are disadvantageous for one or more reasons. Some marks are temporary because of rapid regeneration of appendages and mutilation, as by clipping appendages could affect behavior. Also, mechanical tags either interfere with normal activity, the molting process, or are lost with the exuviae.

\section{REFERENCWS}

ABRAHAMSSON S.A.A., 1965 - A method of marking crayfish Astacus astacus I inne in population studiç. Oikos 16:228-231

APPELLOV A., 1909 - Untersuchungen uber den hummer. Bergens Museums Skrifter 8:1-77, Begen. ARWIDSSON 1., 1914 - Spridda studier over vanliga i samband med kraftmarkninger Sodermanland och Hal. singland. Medd. Kungl. Lantbruksstyrelsen, 192:1-42, Stockholm. 
BLACK J.E., 1963 - Observations on the home range of stream-dwelling crawfishes. Ecology, 44:592-595.CAMOUGIS G. and J.K. HICHAR., 1959 - Some studies on crayfish distribution in a small pond. Amer. Midl. Nat. 62:227-23l.

COOPER J.E. and M.R. COOPER., 1971 - Studies of the aquatic ecology of Shelta Cave, Huntsville, Alabamia. ASB Bull., 18:30 (abstr.).

COOPER M.R. and J.E. COOPER., 1976 - Growth and longevity in cave crayfish. ASB Bull., 23(2):52 (abstr.). COPE E.D., 1871 - Wyandotte Cave and its. life. The Indianapolis J., 5 Sept. 1871:4.

ELI IOTT J.M., 1971 - Upstream movements of benthic invertebrates in a Lake Districk stream. J. Anim. Ecol., 40:235-252.

GEORGE R.W., 1957 - Continuons crayfishing tests: Pelsart group, Houthman Abrolhos, Western Australia, 1953. Australian J. Mar. Freshw. Res. 8:476-490.

GEORGiE R.N., 1958 - The status of the "white" crayfish in Western Australia. Australian J. Mar. Freshw. Res., 9:537-545.

(iOEILNER K.E., 1943 - The life cycle and productivity of the crawfish Cambarus immunis (Hagen). Ph. D. Thesis, Univ. Michigan, Ann Arbor, 1-60.

(iOODMAN D., 1975 - The theory of diversity-stability relationships in ecology. Quart. Rev. Biol., 50(3):237266.

HAZIETT B., RITTSCHOF D. and RUEBENSTEIN D., 1974 - Behavioral biology of the crayfish Orconectes virilis. I. Home Range. Amer. Midl. Nat., 92(2):301-319.

HOBBS H.H., Jr. and THOMAS C., BARR Jr., 1972 - The origins and affinities of the troglobitic crayfishes of North America (Decapoda, Astaidae). II. The genus Orconectes. Smithsonian Contri. Zool., 105:1-84.

HOBBS H.H., Jr., H.H. HOBBS III and M. DANIEL, 1977 - A review of the troglobitic decapod crustaceans of the Americas. Smithsonian Contri. Zool., 244:1-183.

HOBBS III.. H.H. 1973 - The population dynamics of cave crayfishes and their commensal ostracods from southern Indiana. Ph. D. Dissertation, Dept. Zool., Indiana Univ., 1-247.

HOBBS III H.H., 1975 - Distribution of Indiana Cavernicolous Crayfishes and their Ecto-commensal ostracods Int. J. Speleol, 7(1975):273-302.

HOBBS III H.H., 1976 - Observations on the cave-dwelling crayfishes of Indiana. Proc. Internat. Crayfish Simp. Freshwater Crayfish papers from the Second International Symposium on Freshwater Crayfish, Louisiana St. Uni., Dis. Cont. Ed., Baton Rouge, Louisiana, U.S.A. 1 Fig., 405-413.

HOBBS III H.H., 1977 - Studies of the cave crayfish Orconectes inermis inermis Cope (Decapoda, (ambaridae). Part. I: Home Range. Proc. Indiana Acad. Sci., 86:175-176 (abstr.).

HOBBS III H.H., 1978 - Studies of the cave crayfish Orconects inermis inermis Cope (Decapoda, Cambaridae). Part II: (irowth. Ann. Rept. Cave. Res. Found., 20:31-32.

JE:CiL A T.C.., 1965 - Studies of the eyestalk, metabolism, and molting, and reproduction cycles in a cave crayfish. Ph. D. Dissertation, Univ. Illinois. 64-8397. Univ. Micro., Ann Arbor.

JF(il A T.C., 1966 - Reproductive and molting cycles in cave crayfish. Biol. Bull., 130:345-358.

I AN(il OIS T.H., 1937 -Further observations on habits on the crayfish, Cambarus rusticus Girard. Trans. Amer. Fish. Soc., 66:275-276.

MFRKI F I. E. 1967 - The home range and homing ability of the crayfish Orconectes juvenilis in a permanent Kintucky stream. M. S. Thesis, Univ. Kentucky, Lexington, 1-30.

MERKI E I. E., 1969 - Home range of crayfish Orconectes juvenilis. Amer. Midl. Nat., 81:228-235.

MINC KI EY W.I .., 1964 - Upstream movements of Gammarus (Amphipoda) in Doe Run, Meade County, Kenlichs Ecologv, 45:195-197.

IIOBBFER Y W. C., Jr., and R. PFRIMMER., 1967 - Distribution of crayfish in a roadside ditch. Amer. Midl. Vat. $70: 82-88$

II(Ni)T W. T., 1966 - Unstream movement of crayfish in an intermittent Oklahoma stream. Amer. Midl. Val., 75:15()-159.

PAI MI: R A N., 1968 - The survey of Blue Spring Cave, Lawrence County, Indiana. Proc. Indiana Acad. Sci., $77: 245-251$

PAI MI R. N.. 1969 - A hydrologic study of the Indiana karst. Ph. D. Dissertation, Indiana Univ., Univ. Micro. Ann Arbor.

PINN (i.H., Jr., 1943 - A study of the life history of the Louisiana red crayfish, Cambarus clarkii. Ecology, $24: 1-18$

PRINS R., 1968 - (omparative ecology, of the crayfish Orconectes rusticus rusticus and Cambarus tenebrosus in Dor Run. Mcade (ounty, Kentucky. Int. Rev. Gesamten. Hydrobiol., 53:667-714.

R()UNSHIIII (i.A. and W.H. EVERHART., 1953 - Fishery science. John Wiley and Sons, New York 1-444. S( ARRATI D.J 1970 - I aboratory and field tests of modified Sphyrion tags on lobsters (Homarus americaIIus). I. Fish. Res. Bd. Canada, 27:257-264.

SCHIMACHI R F X. and R.W. FSCHMFYER., 1943 - The estimation of fish population in lakes or ponds. $J$. lomne'se' teud Sal. 18:228-249.

SI AC $k k$. A. I 1955 - A vudy of the factors affecting stream productivity by the comparative method. Invest. Indiana I akes and Streams, $4: 3-47$

$S() \mathrm{KA} \mathrm{K} . \mathrm{R}$ and F. I. R()HI F, 1969 - Biometry, the principles and practice of statistics in biological research, 11. H. Fresman and (c). San Francisco, 1-776.

SIRIOSON (.. 1948. Stunted crastish populations in Sweden. Inst. Freshw. Water Res. Drottningholm. Rip.. 29:135.145.

W1I RS 1., |961 Standing crop and drift of steam hottom organisms. Ecology, 42:532-537. 